\title{
APATISME POLITIK PEMILIH PEMULA DAN PAPARAN DRAMA KASUS KORUPSI DI LAYAR KACA
}

\author{
Asmaul Husna \\ Program Studi Ilmu Komunikasi \\ Universitas Teuku Umar \\ Email: asmaulhusna@utu.ac.id
}

\begin{abstract}
Implementation of periodically election periodically show that Indonesia is one of the countries which embrace democratic system. Meanwhile in the process, election requires political participation presences from citizen to declare and define their desire as a source of the legitimacy. However the facts, political participation of the citizen in 2017 's election tend to decrease than a couple years before. This matter occur because amount of corruption news that to be exposed in mass media. It was impact to disappearance of political trust and interest the beginner voters who didn't realize that their apathetic attitude would aggravate to political environtment in Indonesia. This research aim to analysis how the corruption news which reported in mass media take effect about the apathetic attitude of beginner voters. Which uses cultivation theory, this research apply the quantitative approach and positivism paradigm that use survey research. Data collection techniques of probability sampling with 93 respondents samples. With simple linear regression method, was indicate a positive and significant dominant influence about the media access experience of beginner voters with political apathetic tendency, with contribution of influence 73,1\%, $R^{2}=0.0731, \beta=0,855$ and $p<0,01$.
\end{abstract}

Keywords: Beginner Voters, Corruption, Media Effect, Political Apathetic.

\section{A. PENDAHULUAN}

Pelaksanaan Pemilihan Umum secara periodik menunjukkan bahwa Indonesia merupakan salah satu negara yang menganut sistem demokrasi, yaitu pemerintahan yang dilakukan dari rakyat, oleh rakyat, dan kembali kepada kepentingan rakyat melalui perwakilan anggota legislatif (Linz, 2001). Dalam prosesnya, Pemilihan Umum menuntut adanya partisipasi politik dari seluruh warga negara untuk menyuarakan dan menentukan keinginannya secara bebas dan jujur sebagai sumber legitimasinya.

Sejatinya Pemilihan Umum disajikan untuk mengetahui keinginan dan kehendak warga negara tentang apa dan siapa yang layak memimpin dan memberikan perubahan bagi seluruh rakyat dalam suatu negara. Sehingga dapat ditarik sebuah kesimpulan, bahwa sikap apatis adalah musuh besar dari prinsip demokrasi.

Di Indonesia, apatisme politik bukanlah isu baru (Soebagio, 2008; Asfar, 2004). Data KPU menyebutkan bahwa partisipasi politik masyarakat pada Pemilihan Umum Presiden 2014 menurun dari tahun sebelumnya. Dimana suara golput mencapai 29,8 persen atau 56.732.857 suara. Padahal pada tahun 
2009 angka golput hanya mencapai 27,7 persen. Angka ini bahkan lebih buruk jika dibandingkan dengan tahun 2004 yang hanya 24 persen. Dari data tersebut juga ditemukan fakta bahwa kebanyakan yang tidak menggunakan hak suaranya ialah para pemilih pemula.

Fakta tersebut sejalan dengan pendapat yang menyebutkan bahwa sifat apatisme ini lebih sering ditemukan pada pemilih pemula, dikarenakan mereka memiliki tingkat ketidakpercayaan yang tinggi terhadap sistem pemerintahan yang ada (Quinteller, 2007). Mereka lebih tertarik kepada aksi politik yang lebih modern, seperti menjadi aktivis isu-isu sosial layaknya program earth hours, go green, stop racism, hingga aksi perlindungan hewan yang hampir punah. Selain itu, kebanyakan pemilih pemula akan cenderung menghindar jika diajak berdiskusi mengenai persoalan politik dan cenderung mengidentikkan politik dengan hal-hal negatif.

Di tengah setiap orang memiliki kebutuhan informasi yang tinggi dalam menjalani kehidupan, media tampil layaknya etalase politik. Kasus korupsi selalu menjadi liputan utama media setiap harinya. Media menggiring opini publik untuk tidak lagi percaya kepada para elit politik dengan modus membantu publik untuk mengevaluasi setiap langkah dan gerak-gerik para elit politik yang mana hal tersebut berimbas langsung pada hancurnya kepercayaan para pemilih pemula terhadap dunia politik. Bahkan hasil survei Indikator Politik Indonesia (2013) mampu memberikan gambaran bahwa tingkat ketidakpercayaan pemilih terhadap Presiden mencapai 26 persen, para Menteri 36 persen, DPR 49 persen, Politisi 57 persen, dan Parpol 58 persen. Dimana fenomena ini tidak lepas dari pengaruh konsumsi berita politik yang ditayangkan oleh media. Maka tidak dapat dipungkiri, media telah berkontribusi terhadap penurunan partisipasi politik di Indonesia.

Hingga akhirnya muncul anggapan bahwa tidak adanya calon yang dapat membawa perubahan atau setidaknya memberi harapan yang kongkrit membuat para pemilih pemula enggan berpartisipasi dalam kegiatan politik atau lebih memilih bersikap apatis. Padahal tanpa disadari keacuhan mereka justru memperburuk keadaan politik Indonesia. Sikap apatis mereka justru memberikan kesempatan kepada elite politik lama tetap bertahan dan semakin memporak-porandakan sistem politik Indonesia. Sebab hanya dengan partisipasi politik merekalah yang memungkinkan terjadinya proses perekrutan elite politik yang baru. Dengan begitu sikap apatis pemilih pemula memiliki implikasi yang buruk bagi masyarakat maupun sistem pemerintahan Indonesia. 


\section{B. KAJIAN TEORITIK}

\section{Mass Media Effect}

Dewasa ini, apapun yang kita ketahui mengenai dunia kita peroleh dari media massa. Begitu pentingnya media, sehingga perannya begitu dahsyat dalam proses pembentukan masyarakat yang lebih dewasa dan modern (Willnat, 1996; Hutapea, 2010; Hadi, 2007). Sedemikan hebatnya efek media, hingga dewasa ini manusia seolah bergantung padanya. Berita dan opini yang dipaparkan secara reguler di media, memandu publik untuk menghubungkan berbagai realitas yang sebelumnya terpisah oleh faktor geografi dan psikografi menjadi satu rangkaian yang bisa diikuti dan dipahami secara mudah. Dengan kemampuannya, media dapat dengan mudah mengubah standar evaluasi yang digunakan khalayak untuk menilai realitas sosial yang dihadapinya. Masyarakat semakin tidak bisa membedakan mana yang realitas sebenarnya, mana yang realitas dalam media. Padahal tidak selamanya yang disampaikan oleh media adalah benar (Luhmann, 2000).

Dalam kurun waktu 13 tahun terakhir sejak terbentuknya Komisi Pemberantasan Korupsi pada masa kepemimpinan Presiden Susilo Bambang Yudoyono, hampir setiap hari selalu ada kasus korupsi elit politik yang terendus dan diberitakan secara bombastis oleh media. Mulai dari kasus korupsi dengan angka ratusan juta hingga triliyunan semua dibongkar habis di media. Bahkan dalam setahun pemerintahan jokowi saja, tercatat sudah 9 Menteri, 19 Gubernur, dan 300 Bupati dan Walikota dipenjara berkat kasus korupsi (Detik.Com, 2015). Pada tahap ini, media tidak hanya menjadi cermin dari kehidupan politik, tetapi juga melakukan generalisasi atas realitas politik dengan melakukan konstruksi realitas politik sebagai sesuatu yang bersifat kompleks serta mengundang antusiasme respon publik (Meyer, 2002).

Disadari atau tidak, semakin sering pemaparan media mengenai kasus yang bermuatan politik, maka kecenderungan untuk menimbulkan dampak atau perubahan psikologis masyarakat terhadap politik akan semakin besar (Kaid, 2015). Penyataan tersebut pun sejalan dengan asumsi teori kultivasi milik Gerbner, dimana disebutkan bahwa semakin banyak seseorang menghabiskan waktu untuk mengakses media, semakin kuat kecenderungan orang tersebut menyamakan realitas media dengan realitas sosial (Straubhaar, 2010). Maka bukan tidak mungkin intensitas dan frekuensi pemaparan media yang secara terus menerus memberitakan mengenai kasus korupsi sejumlah elit politik, secara tidak langsung memiliki pengaruh yang cukup signifikan terhadap atensi, persepsi, kepercayaan, dan tindakan pada pemilih pemula dalam memandang budaya dan institusi politik (Stamm, 1990). 


\section{Partisipasi Politik Dan Media}

Dalam perspektif ilmu komunikasi politik, partisipasi politik dapat diartikan sebagai upaya individu sebagai warga negara untuk ikut serta dalam mempengaruhi bentuk kebijakan publik dalam sebuah negara dan sebagai bentuk rasa tanggung jawabnya dalam kehidupan berpolitik. Partisipasi politik merupakan aspek penting dalam sebuah tatanan negara demokrasi. Secara umum partisipasi politik sendiri dapat dikategorikan dalam beberapa bentuk (Firmanzah, 2008) yaitu, electoral activity yaitu segala bentuk kegiatan baik secara langsung maupun tidak berkaitan dengan pemberian suara dalam pemilihan, organizational activity yaitu keterlibatan seseorang dalam organisasi politik, dan melakukan diskusi politik atau demonstrasi.

Dalam beberapa riset dikatakan partisipasi politik sangat dipengaruhi oleh kepercayaan dan ketertarikan seseorang atas politik (McQuail, 1994; Oskarson, 2008; Putra, 2014; Yuliono, 2013; IPI, 2013). Dengan kata lain, rendahnya kepercayaan dan ketertarikan masyarakat terhadap politik akan berimbas sebaliknya, yaitu apatisme politik. Gejala dari apatisme politik ini dapat dilihat dari kurangnya ketertarikan terhadap politik, ketidak percayaan terhadap institusi politik, dan keengganan seseorang untuk berpartisipasi dalam hal-hal yang berbau politik. Dan gejala ini terlihat jelas khususnya pada individu yang berumur 17 hingga 22 tahun. Padahal menurut beberapa ahli politik dan pemerintahan mereka diindentifikasikan sebagai tokoh utama dalam kinerja sistem demokrasi.

Sebagai salah satu dari beberapa agen sosialisasi, media memberikan banyak bahan baku preferensi dan agregasi yang kemudian dapat membentuk kepercayaan dan sikap politik pada pemilih pemula. Pemilih pemula yang belum terjun secara aktif ke dunia politik mengikuti perkembangan politik melalui media. Paparan media yang mereka konsumsi semakin hari semakin membentuk pengetahuan politik mengenai pemimpin, institusi politik, partisipasi politik, serta keyakinan politik mereka (Carpini, 2000).

Dalam sebuah studi disebutkan bahwa, anak muda atau dalam penelitian ini disebut dengan pemilih pemula, bersentuhan dengan media dalam frekuensi yang cukup sering dengan intensitas 4 hingga 6 jam setiap harinya, atau dapat dikatakan mereka tumbuh bersama media. Sehingga jelas apabila sejak usia dini para pemilih pemula sudah mendapatkan informasi mengenai kasus korupsi para elit politik, maka hal ini tentu berimbas pada hancurnya kepercayaan dan ketertarikan para pemilih pemula pada dunia politik. Semakin sering mereka melihat pemaparan media mengenai kasus korupsi, maka mereka akan berpikir bahwa para elit politik tidak ada yang benar-benar memperjuangkan nasib rakyat, namun justru memperkaya diri sendiri dengan menggunakaan kekuasaannya dan menghalalkan segala cara. 
Hingga akhirnya, akumulasi kekecewaan terhadap realitas politik yang dirasakan oleh pemilih pemula bertambah pada membentuk sikap apatis politik, yang mana sikap tersebut memiliki tiga dimensi utama yaitu kognitif yaitu dimensi yang berhubungan dengan pikiran negatif dan ketidak tertarikan pemilih pemula terhadap politik, afektif yaitu dimensi yang berhubungan perasaan pemilih pemula yang kemudian menjadi tidak lagi percaya pada politik serta institusi di dalamnya, dan konatif yaitu dimensi yang berkaitan dengan kecenderungan perilaku pemilih pemula untuk tidak ingin terlibat dalam kegiatan partisipasi politik apapun.

Selain itu, menurut Quinteler (2007) ada dua hal yang menjadi penyebab utama para pemilih pemula tidak lagi tertarik terhadap politik. Pertama, menurut mereka politik tidak merefleksikan persepsi para pemilih pemula. Kedua, pemilih pemula merasa kurang dilibatkan dalam sistem politik dikarenakan mereka masih muda, sehingga perpektif dan kepedulian pemilih pemula dalam politik tidak terwakili dengan baik. Menurut mereka, pemilih pemula cenderung dijadikan sebagai objek politik ketimbang subjek politik.

Hal inilah yang kemudian dianggap beberapa ahli mendasari ketidaktertarikan pemilih pemula pada politik. Selain itu, carut-marutnya supremasi hukum dan kegusaran atas perilaku elit politik yang tak sesuai dengan janji-janji saat kampanye meningkatkan faktor ketidak percayaan para pemilih pemula. Hingga dapat diasumsikankan apatisme politik merupakan akumulasi kekecewaan dan ketidak percayaan terhadap realitas politik yang dilihat kemudian disalurkan melalui suara golput terhadap dalam setiap Pemilihan Umum.

\section{Hipotesis Dan Rumusan Masalah}

$\mathrm{H}_{1}$ : Semakin tinggi frekuensi pemilih pemula mengakses media, maka semakin apatis pula sikap mereka. $\mathrm{H}_{2}$ : Semakin tinggi intensitas pemilih pemula mengakses media, maka political trust mereka akan semakin rendah.

RQ: Adakah dampak yang ditimbulkan oleh pemberitaan media seputar kasus korupsi terhadap sikap apatis politik pemilih pemula?

\section{Kerangka Operasional}

Dalam penelitian ini terdapat dua variabel. Pertama, pengalaman bermedia pemilih pemula dianggap sebagai variabel independen atau variabel x. media dalam hal ini meliputi televisi, koran, radio, dan portal online. Dengan dimensi frekuensi (tingkat keseringan) pemilih pemula mengakses media, intensitas (durasi) pemilih pemula menyimak berita mengenai kasus korupsi, dan atensi (ketertarikan) pemilih pemula dalam menyimak berita terkait kasus korupsi. 
Sedangkan, variabel kedua atau variabel y yang merupakan variabel dependen yaitu sikap apatis pemilih pemula. Dimana dimensi pembentuk dari sikap apatis sendiri ialah tingkat ketertarikan pemilih pemula terhadap politik (kognitif), tingkat kepercayaan pemilih pemula terhadap institusi politik (afektif), dan kecenderungan perilaku pemilih pemula terhadap politik (konatif).

\section{METODE PENELITIAN}

Penelitiaan ini menggunakan pendekatan kuantitatif dengan menggunakan paradigma positivism dimana peneliti menempatkan teori sebagai titik tolak utama dalam kegiatan penggalian informasi kebenaran. Pendekatan kuantitatif dipilih pendekatan ini dapat memberikan gambaran informasi yang faktual dan mendetail mengenai dampak yang ditimbulkan oleh pemberitaan media seputar kasus korupsi terhadap sikap apatis pemilih pemula, sehingga kita dapat menjustifikasi keadaan (gejala) yang sedang terjadi dalam masyarakat.

Berdasarkan tujuannya, penelitian ini tergolong penelitian eksplanatif yang artinya penelitian ini berusaha menjelaskan hukum kausal dalam memprediksi suatu fenomena, dan dalam penelitian ini peneliti ingin melihat dampak pemberitaan media mengenai kasus korupsi terhadap sikap apatis pemilih pemula. Sedangkan berdasarkan dimensi waktu penelitian ini masuk ke dalam single cross sectional dimana pengambilan data dilakukan pada satu sampel dalam kurun waktu satu kali pengambilan.

Adapun objek dalam penelitian ini adalah 93 orang pemuda-pemudi yang berdomisili Di Kota Banda Aceh dengan rentang usia 17 hingga 22 tahun yang mana dapat dikategorikan sebagai pemilih pemula serta pernah terlibat dalam kegiatan Pemilihan Kepala Daerah Aceh pada tahun 2017. Penentuan lokasi penelitian dikarenakan pada Pemilihan Kepala Daerah Aceh pada tahun 2017, Kota Banda Aceh memiliki angka Golongan Putih yang cukup tinggi yakni mencapai 57.365 orang atau sekitar 37,3 persen dari jumlah pemilih tetap 151.105 orang. Angka ini bahkan lebih tinggi daripada angka perolehan calon walikota yang tidak terpilih pada masa itu yakni hanya 32 persen atau sekitar 31.355 suara. Sedangkan penentuan sampel dalam penelitian ini menggunakan probability sampling dengan teknik acak sederhana karena jumlah populasi yang tidak terlalu besar dan cenderung homogen.

\section{Teknik Pengumpulan Data Dan Analisis Data}

Metode pengumpulan data dalam penelitian ini yaitu dengan menggunakan teknik survei langsung terstruktur melalui kuesioner terbuka yang sudah disediakan dan berisikan beberapa pertanyaan terstruktur sesuai dengan variabel operasional penelitian serta pilihan jawaban yang nantinya akan diukur menggunakan skala likert. Kuesioner dibagikan secara langsung dengan maksud agar peneliti dapat 
memberikan penjelasan mengenai maksud serta tujuan pengisian kuesioner tersebut. Selain itu, peneliti turut menitipkan beberapa kuesioner kepada responden yang telah berpartisipasi dalam penelitian ini guna membantu menyebarkan kuesioner, sehingga akan lebih mengefisienkan waktu penelitian.

Sedangkan teknik analisis data hasil penelitian menggunakan metode simple linear regression, untuk menguji rangkaian pengaruh antara satu varibel terikat dengan satu variabel bebas (Umar, 2000). Dimana peneliti mengambil nilai-nilai $X$ untuk melakukan estimasi atau memprediksi nilai $Y$, atau disebut dengan simple prediction. Dan untuk memudahkan proses pengolahan data, maka dalam hal ini akan dibantu dengan program SPSS for Windows version 19.

\section{Uji Validitas Dan Reliabilitas}

Setelah diperoleh data dan informasi dari pengisian kuesioner, maka selanjutnya akan dilakukan uji validitas dan reliabilitas. Uji validitas akan dilakukan dengan menggunakan bantuan program software SPSS SPSS for Windows version 19. Rumus yang berlaku nantinya dengan menggunakan syarat jika ${ }^{\mathrm{r} h i t u n g} \geq{ }^{\mathrm{r}}$ tabel dengan taraf signifikansi 97\%, instrumen tersebut dinyatakan valid, namun jika ${ }^{\mathrm{r} h i t u n g} \leq$ ${ }^{r}$ tabel dengan taraf signifikansi $97 \%$ instrumen tersebut akan dinyatakan tidak valid. Sedangkan uji reliabilitas pada penelitian ini dilakukan dengan melihat jawaban responden dalam kuesioner. Kuesioner dinyatakan reliabel jika jawaban-jawaban responden pada kuesioner tersebut termasuk konsisten atau stabil. Dalam program SPSS, pengujian ini dilakukan dengan metode Cronbach Alpha, artinya kuesioner akan dinyatakan reliabel apabila nilai Cronbach Alpha $>0,6$.

\section{Limitasi Riset}

Penelitian ini tentu memiliki keterbatasan, dimana keterbatasan menyangkut perihal minimnya jumlah populasi dan sampel yang dijadikan objek dalam penelitian dan kemungkinan pertanyaan dalam kuesinoer yang belum cukup menjawab permasalahan yang diangkat dalam penelitian. Untuk itu peneliti meminta maaf sebesar-besarnya.

\section{HASIL DAN PEMBAHASAN}

\section{Media Dan Pemilih Pemula}

Dari hasil penelitian ditemukan bahwa para pemilih pemula memiliki frekuensi yang cukup tinggi dalam mengakses media yaitu lebih dari 5 kali dalam satu hari, dengan durasi rata-rata 1 hingga 4 jam dalam sekali akses, atau dengan kata lain mereka akan bersentuhan dengan media tak kurang dari 4 jam dalam sehari. Tak heran jika kemudian para pemilih pemula dikatakan sebagai generasi yang tumbuh bersama media. 

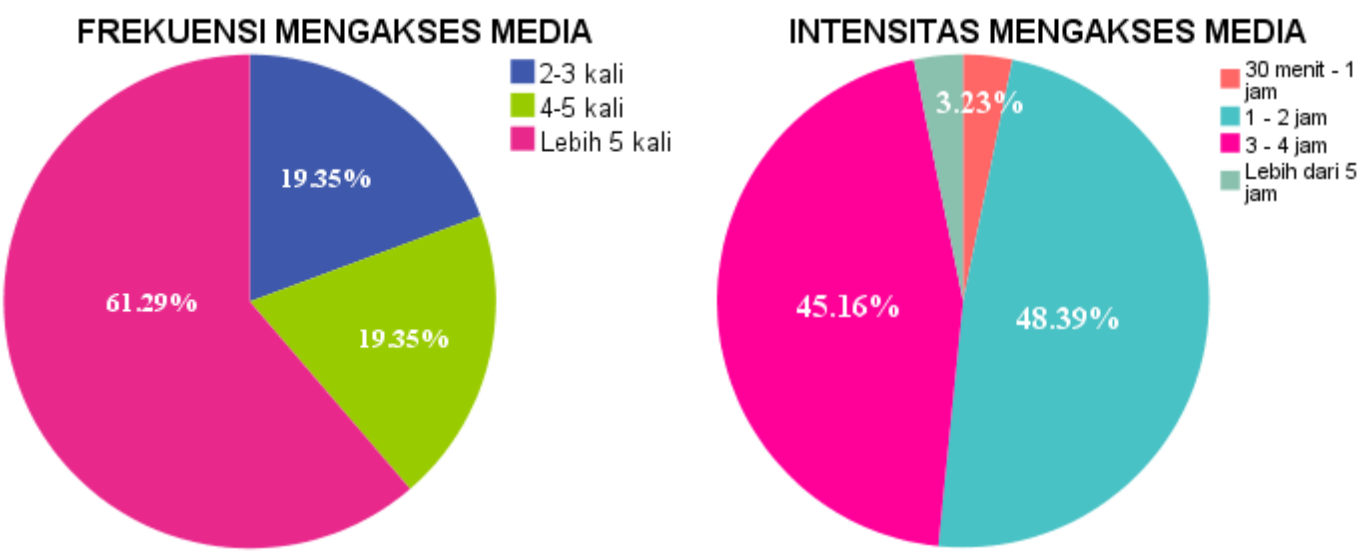

Sementara itu jika diamati, meskipun frekuensi dan intensitas penggunaan media para pemilih pemula relatif tinggi, akan tetapi hanya 42 orang dari pemilih pemula yang tertarik terhadap pemberitaan korupsi di media atau sebanyak 45,16 persen, dan hanya 18 orang yang menyatakan ketertarikannya pada politik yaitu dengan prosentase 19,35 persen.
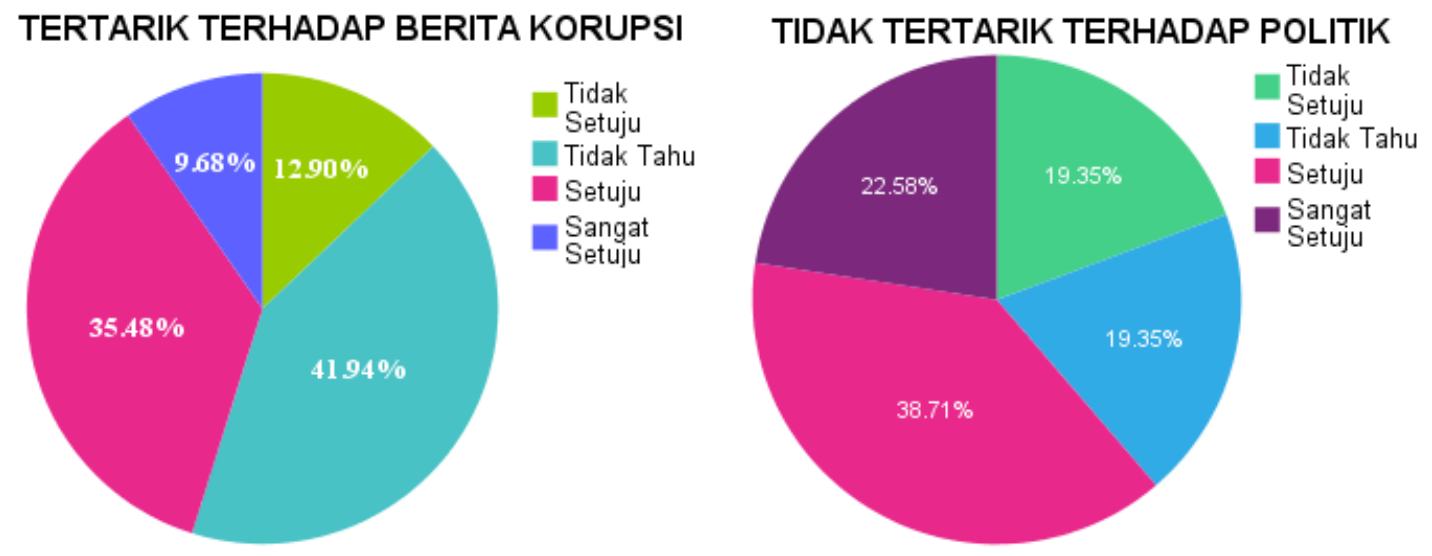

Menariknya, meskipun tidak sepenuhnya dari para pemilih pemula menyatakan ketertarikannya terhadap berita mengenai kasus korupsi yang dipaparkan oleh media setiap harinya, hal ini bukan berarti mereka tidak tahu dan menutup mata begitu saja. Terlihat bahwa setidaknya seluruh pemilih pemula mengetahui dan dapat menyebutkan siapa saja pelaku korupsi yang pernah di blow up oleh media.

Dimana dalam hasil penelitian menunjukkan sebanyak 38.71 persen atau 36 orang pemilih pemula mampu menyebutkan 2 sampai 3 kasus korupsi dan 36 orang lainnya mengetahui dan mampu menyebutkan 4 sampai 5 kasus korupsi dengan jumlah prosentase yang sama, yaitu 38,71 persen. 
Sedangkan sisanya, sebanyak 22,58 persen atau 21 orang bahkan mampu menyebutkan lebih dari 5 kasus korupsi. Dan kasus korupsi mega dana wisma atlet Hambalang, E-KTP, Papa Minta Saham adalah 3 kasus korupsi yang paling melekat dalam ingatan mereka.

Ketika ditelusuri lebih lanjut mengenai bagaimana intensitas para pemilih pemula dalam menyimak pemberitaan korupsi di media, ternyata sebanyak 30 orang atau 32,26 persen mengatakan bahwa mereka hanya mengikuti pemberitaaan di awal kemunculannya saja. Sebanyak 29,03 persen atau 27 orang hanya sekedar ingin tahu hukuman apa yang ditetapkan kepada para pelaku korupsi. 19,35 persen atau 18 orang mengikuti pemberitaan sejak awal hingga penyelesaian kasus, 16,13 persen atau 15 orang hanya sekedar ingin tahu siapa pelaku korupsi dan berapa nilai korupsi yang dilakukannya, dan sisanya 3,23 persen atau 3 orang hanya sekedar membaca judul yang ada di media.

\section{MENYIMAK BERITA KORUPSI}
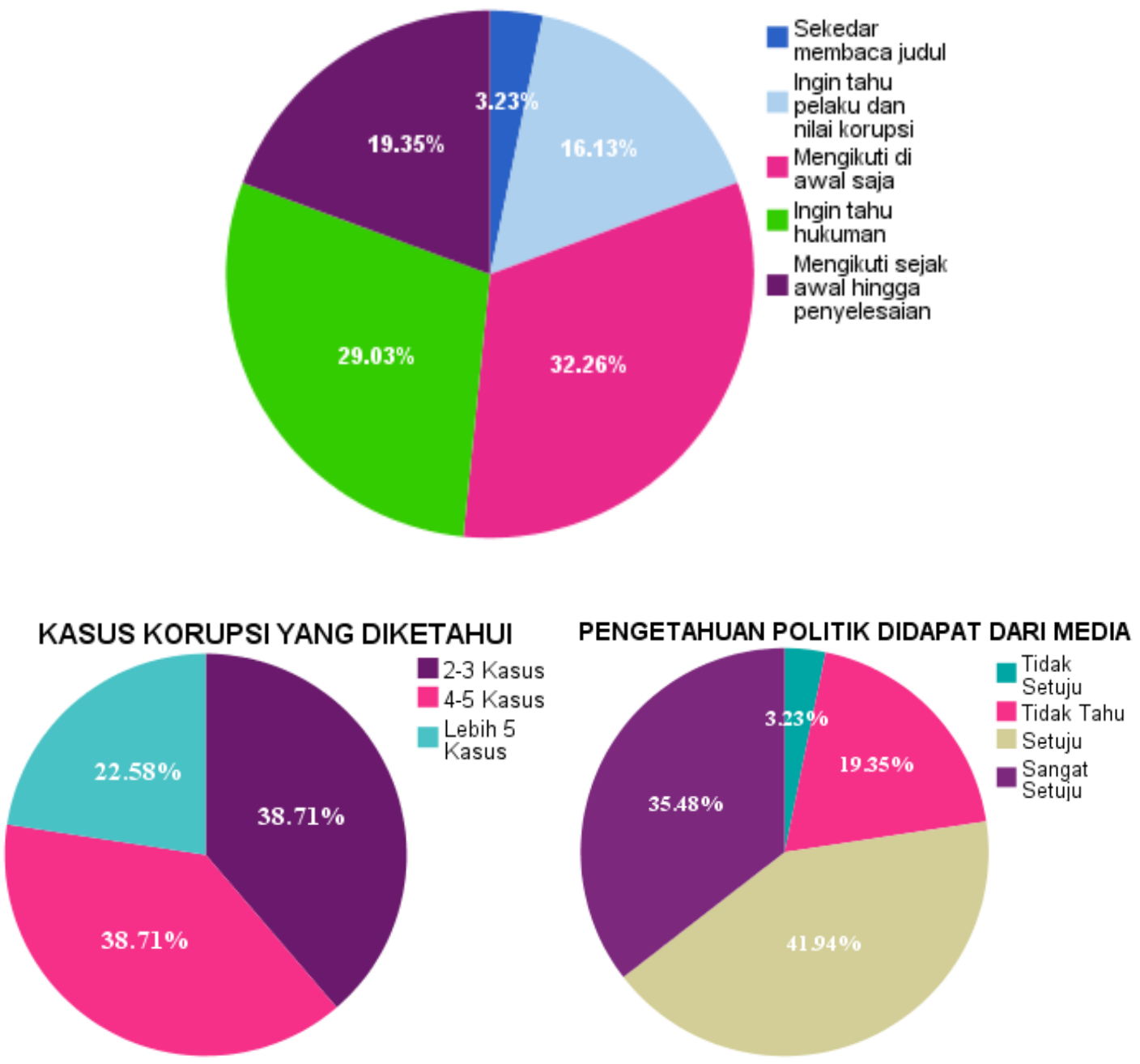
Minimnya pengalaman politik yang dimiliki oleh para pemilih pemula, mengakibatkan pengetahuan politik mereka menjadi cenderung termediasi. Terbukti media dalam hal ini memiliki pengaruh besar terhadap pengetahuan politik para pemilih pemula, dimana dalam hasil penelitian menunjukkan bahwa sebanyak 72 orang pemlih pemula atau 77,42 persen mengatakan bahwa mereka mendapatkanya melalui media. Dengan intensitas dan frekuensi yang cukup tinggi dalam mengkonsumsi media setiap harinya serta pengalaman politik yang cenderung minim dan termediasi, maka hal ini terbukti memiliki kontribusi cukup kuat terhadap terbentuknya sikap apatis politik para pemilih pemula.

Kemudian ditemukan pula adanya korelasi yang cukup kuat mengenai pengalaman bermedia dengan tingkat political trust. Dimana hal tersebut terlihat dalam poin pertanyaan mengenai tingkat kepercayaan pemilih pemula terhadap media, elit politik dan partai politik. 48 orang atau sebanyak 51,61 persen memilih untuk tidak lagi percaya pada elit politik, 60 orang atau 64,51 persen merasa bahwa elit politik yang ada saat ini tidak benar-benar memperjuangkan nasib rakyat, dan 69 orang atau sebanyak 74,2 persen menyatakan ketidakpercayaannya terhadap partai politik.
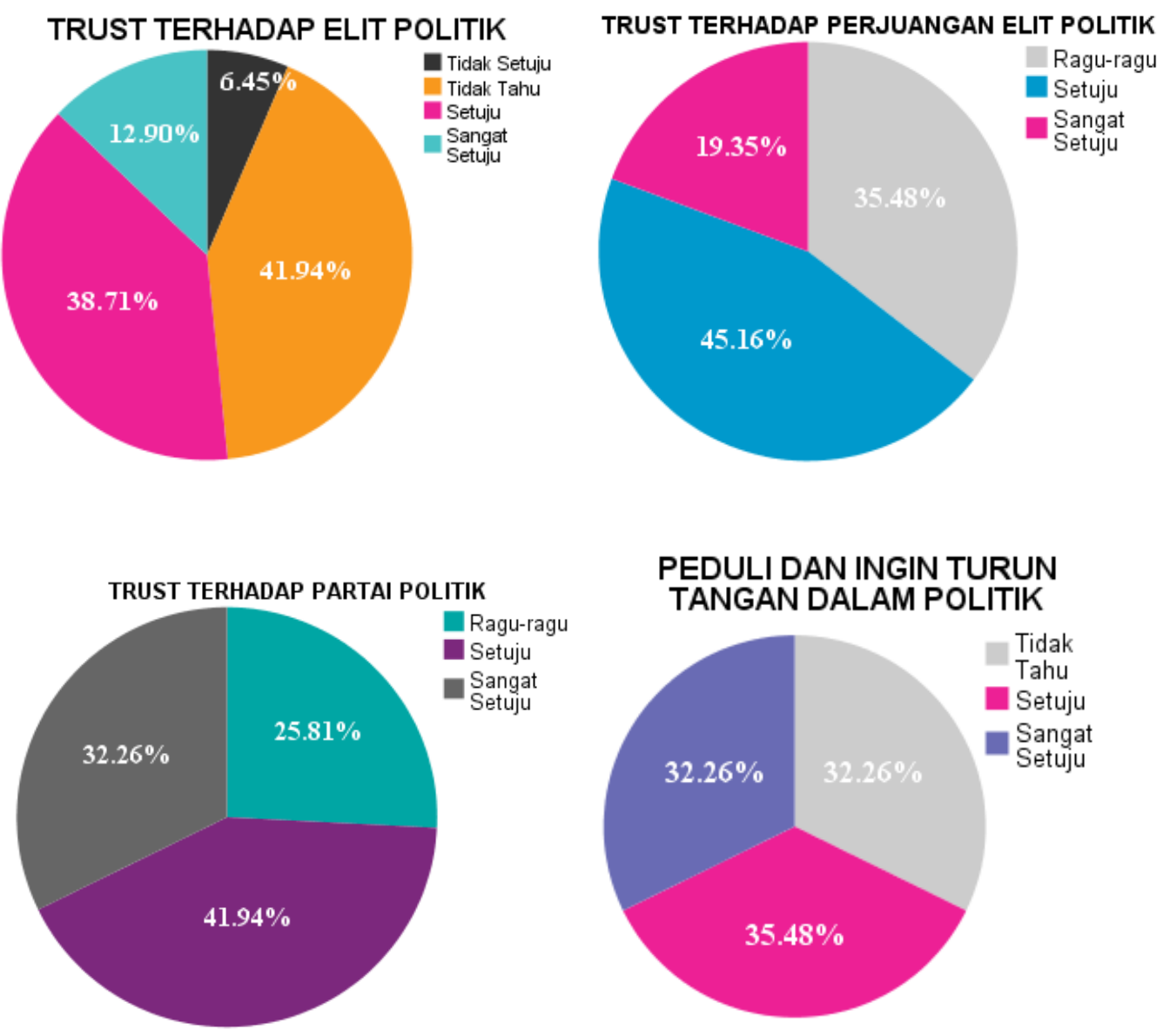

PEDULI DAN INGIN TURUN TANGAN DALAM POLITIK

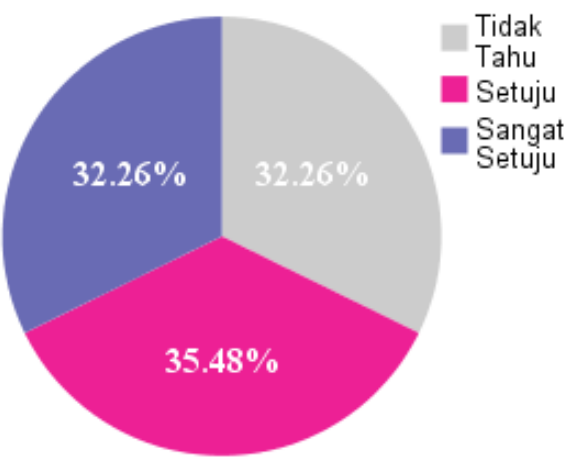


Dalam deretan angka-angka tersebut terlihat jelas bahwa para pemilih pemula, memiliki kecenderungan untuk tidak lagi percaya terhadap partai dan para elit politik karena mereka menganggap bahwa para elit yang ada saat ini tidak benar-benar memperjuangkan nasib mereka. Dimana hal ini muncul akibat tingginya intensitas dan frekuensi para pemilih pemula dalam mengakses media.

Namun meskipun political trust pemilih pemula cenderung rendah, akan tetapi sikap apatis politik ini tidak sepenuhnya terwujud dalam aspek kognitif mereka. Hal ini terlihat dalam poin pertanyaan mengenai keinginan pemilih pemula untuk berpartisipasi dalam kancah politik. Dimana terbukti sebanyak 67,74 persen atau 63 orang pemilih pemula masih merasa peduli dan ingin turun tangan langsung untuk melakukan perubahan dalam ranah politik di Indonesia. Dan terlihat tidak ada satupun dari mereka yang merasa tidak ingin berpartisipasi lagi dalam kegiatan politik.

\section{Model Summary}

\begin{tabular}{|c|c|c|c|c|}
\hline Model & $\mathrm{R}$ & R Square & Adjusted R Square & Std. Error of the Estimate \\
\hline 1 & $.855^{\mathrm{a}}$ & .731 & .722 & 3.03891 \\
\hline
\end{tabular}

a. Predictors: (Constant), pengalaman bermedia pemilih pemula

b. Dependent Variable: sikap apatis pemilih pemula

Coefficients $^{\mathbf{a}}$

\begin{tabular}{|c|c|c|c|c|c|}
\hline \multirow{2}{*}{ Model } & \multicolumn{2}{|c|}{$\begin{array}{c}\text { Unstandardized } \\
\text { Coefficients }\end{array}$} & $\begin{array}{c}\text { Standardized } \\
\text { Coefficients }\end{array}$ & $\mathrm{t}$ & \multirow{2}{*}{ Sig. } \\
\cline { 2 - 4 } & $\mathrm{B}$ & Std. Error & Beta & & \\
\hline $\begin{array}{c}\text { (Constant) } \\
\text { PENGALAMAN BERMEDIA } \\
\text { PEMILIH PEMULA }\end{array}$ & 8.014 & 3.954 & & 2.027 & .052 \\
& 1.048 & .118 & .855 & 8.876 & .000 \\
\hline
\end{tabular}

a. Dependent Variable: sikap apatis pemilih pemula

Sementara itu, dalam hasil pengujian korelasi Pearson terhadap variabel $\mathrm{x}$ yaitu pengalaman bermedia pemilih pemula dan variabel y sikap apatis pemilih pemula memperlihatkan bahwa ada hubungan yang positif, kuat, dan signifikan. Dimana $\mathrm{r}(93)=0,855$ dan $p<0,01$ dengan besar kontribusi pengaruh $\mathrm{X}$ terhadap $\mathrm{Y}$ sebesar $73,1 \%$, yang artinya semakin sering pemilih pemula mengakses media maka akan semakin kuat pula kecenderungan sikap apatis politik mereka. Maka, hipotesis dalam penelitian ini dapat dinyatakan terbukti sepenuhnya. 
Sedangkan sebanyak 26,9\% sisanya, disebabkan oleh faktor lain seperti pengaruh keluarga, teman, lingkungan, ataupun pengalaman pendidikan politik yang pernah didapatkan oleh para pemilih pemula dan faktor lainnya di luar penelitian ini yang tidak teridentifikasi dan memerlukan penelitian lebih lanjut lagi.

\section{E. KESIMPULAN}

Pemilih pemula memang tak bisa dipisahkan dari media. Mereka tumbuh dan berkembang bersama media. Minimnya pengalaman politik yang mereka miliki, mengakibatkan pengetahuan politik mereka pun menjadi cenderung termediasi. Media membantu dan memberikan mereka banyak bahan baku preferensi dan agregasi yang kemudian membentuk kepercayaan dan sikap politik pada pemilih pemula. Berdasarkan data dan hasil analisis yang telah dipaparkan sebelumnya, ada beberapa hal yang bisa digaris bawahi untuk melihat jalinan hubungan tersebut, yaitu:

1. Semakin tinggi frekuensi pemilih pemula mengakses media yang menayangkan mengenai kasus korupsi yang melibatkan elit politik, maka kecenderungan sikap apatis politik mereka akan semakin terbentuk.

2. Intensitas konsumsi media tinggi, memiliki pengaruh yang cukup kuat dan signifikan terhadap rendahnya political trust pemilih pemula. Namun meskipun political trust pemilih pemula cenderung rendah, akan tetapi sikap apatis politik ini tidak sepenuhnya terwujud dalam aspek kognitif mereka. Terbukti bahwa pemilih pemula masih merasa peduli dan ingin turun tangan langsung untuk melakukan perubahan dalam ranah politik di Indonesia.

3. Hasil pengujian korelasi Pearson terhadap pengalaman bermedia pemilih pemula dengan sikap apatis pemilih pemula memperlihatkan bahwa ada hubungan yang positif, kuat, dan signifikan dengan besar kontribusi pengaruh sebesar $73,1 \%$. Sedangkan sebanyak 26,9\% sisanya, disebabkan oleh faktor lain di luar penelitian ini. Sehingga hipotesis dalam penelitian ini dapat dinyatakan terbukti sepenuhnya.

Sebagai penutup, penelitian ini menunjukkan bahwa para pemilih pemula masih menjadikan media sebagai sumber utama informasi politik mereka, meski disaat yang bersamaan mereka juga sadar bahwa media tidak sepenuhnya memberritakan informasi secara akurat, independen, dan obyektif. Namun jika media massa dan para elit politik tidak juga mulai berbenah diri, maka jangan heran jika kemudian tingkat apatisme pemilih pemula terhadap politik cenderung semakin bertambah dalam setiap periode yang berujung pada partisipasi politik kian menurun. Dan tak pelak, negara dengan slogan demokrasi ini pun berada di ujung tanduk. 


\section{DAFTAR PUSTAKA}

Asfar, M. (2004). Presiden Golput. Surabaya: Jawa Pos Press.

Carpini, M X D. (2000). Gen.Com: Youth, Civic engagement, and the New Information Environment. Political Communication. Vol.17.

Detik.Com. (2015, Oktober 26). Laporan dari Washington DC. Jokowi: 9 Menteri, 19 Gubernur, 300 Bupati/Walikota Dipenjara.

Firmanzah. (2008). Marketing Politik: Antara Pemahaman dan Realitas.Jakarta: Yayasan Obor Indonesia.

Hadi, I. P. (2007). Cultivation Theory: Sebuah Perspektif Teoritik dalam Analisis Televisi. Jurnal Ilmiah Scriptura Universitas Petra Surabaya. Vol. 1, No. 1.

Hutapea, B. (2010). Studi Korelasi Intensitas Menonton Tayangan yang Mengandung Kekerasan di Televisi dengan Perilaku Agresif pada Anak. Jurnal Ikon Universitas Tarumanegara Jakarta. Vol. 3. No.2

Indikator Politik Indonesia. (2013). Internet, Apatisme, dan Alienasi Politik. Jakarta Pusat.

Kaid, L L. (2015). Handbook of Political Communication Research. Bandung: Nusa Media.

Linz, J J. (2001). Menjauhi Demokrasi Kaum Penjahat: Belajar dari Kekeliruan Negara-negara Lain. Bandung: Mizan.

Luhmann, N. (2000). The Reality of the Mass Media. Cambridge: Polity Press.

McQuail, D. (1994). Mass Communication Theory. London: Sage Publications

Meyer, T. (2002). Media Democracy, How The Media Colonize Politics. London: Polity Press

Oskarson, M. (2008). Social Risk and Political Alienation. Norway: Nordic Political Assocoation Paper.

Pangabean. (1994). Pendidikan Politik dan Kaderisasi Bangsa. Jakarta: Sinar Harapan.

Putra, A. A. J. (2014). Jurnal Media dan Politik Anak Muda. Pindai.org

Prijono, O. (1987). Kebudayaan Remaja dan Sub-Kebudayaan Delikeun. Jakarta: CSIS.

Quinteller, E (2007). Differences in Political participation between young and old people: Contemporary politics. Vol. 13 No. 2.

Soebagio. (2008). Makara: Sosial Humaniora: Implikasi Golongan Putih Terhadap Pembangunan Demokratisasi di Indonesia. Vol 12 No 2. 
Stamm, K. R, dan John E. B. (1990). The Mass Communication Procces: A Behavioral and Social Perspective. Dubuque: Hunt Publishing Company.

Straubhaar, Joseph, LaRose, Robert, \& Davenport, L. (2010). Media Now: Understanding Media, Culture and Technology, 6th edition. Belmont, CA: Wadsworth (JS).

Sutanto, L. (2004). Siapa Mau Jadi Presiden: Memilih Pemimpin Transisional. Jakarta: Kompas.

Umar, H. (2000). Metode Penelitian untuk Skripsi dan Tesis. Jakarta: Rja Grafindo Persada.

Willnat, L. (1996). Mass Media and Political Outspokenness in Hong Kong: Linking the Third-Person Effect and the Spiral of Silence. Internastional Journal of Public Opinion Research Oxford. Vol. 8, No.2. Halaman. 187-212.

Yuliono, A. (2013, Juni). Jurnal Administrasi Publik: Kepercayaan Masyarakat Pada Partai Politik. Vol.11 No.1. 